\title{
Fibroblast growth factor-2 alleviates the capillary leakage and inflammation in sepsis
}

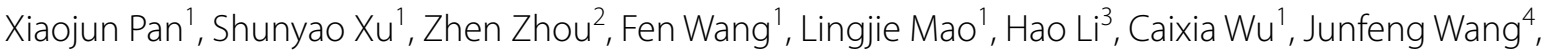 \\ Yueyue Huang ${ }^{1}$, Dequan $\mathrm{Li}^{5^{*}}$, Cong Wang ${ }^{3^{*}}$ and Jingye Pan ${ }^{1 *}$ (])
}

\begin{abstract}
Background: Acute lung injury (ALI), which is induced by numerous pathogenic factors, especially sepsis, can generate alveolar damage, pulmonary edema and vascular hyper-permeability ultimately leading to severe hypoxemia. Fibroblast growth factor-2 (FGF2) is an important member of the FGF family associated with endothelial cell migration and proliferation, and injury repairment. Here, we conducted this study aiming to evaluate the therapeutic effect of FGF2 in sepsis-induced ALI.

Methods: Recombinant FGF2 was abdominally injected into septic mice induced by cecal ligation and puncture $(C L P)$, and then the inflammatory factors of lung tissue, vascular permeability and lung injury-related indicators based on protein levels and gene expression were detected. In vitro, human pulmonary microvascular endothelial cells (HPMEC) and mouse peritoneal macrophages (PMs) were challenged by lipopolysaccharides (LPS) with or without FGF2 administration in different groups, and then changes in inflammation indicators and cell permeability ability were tested.
\end{abstract}

Results: The results revealed that FGF2 treatment reduced inflammation response, attenuated pulmonary capillary leakage, alleviated lung injury and improved survival in septic mice. The endothelial injury and macrophages inflammation induced by LPS were inhibited by FGF2 administration via AKT/P38/NF-kB signaling pathways.

Conclusion: These findings indicated a therapeutic role of FGF2 in ALI through ameliorating capillary leakage and inflammation.

Keywords: FGF2, ALI, Inflammation, Permeability

\section{Introduction}

Sepsis, featured by systemic inflammatory response syndrome (SIRS), is caused by infection and can develop into multiple-organ injury, multiple organ failure and shock (Rhodes et al. 2017). Despite the advances in healthcare, the death rates of patients with sepsis remain high

\footnotetext{
*Correspondence: lidequan0814@163.com; cwang@wmu.edu.cn; wmupanjingye@126.com

${ }^{1}$ Department of Intensive Care Unit, The First Affiliated Hospital of Wenzhou Medical University, Wenzhou 325000, Zhejiang, P. R. China ${ }^{3}$ Wenzhou Medical University, Wenzhou 325000, Zhejiang, P. R. China ${ }^{5}$ Department of Traumatology Medicine, The First Affiliated Hospital of Wenzhou Medical University, Wenzhou 325000, Zhejiang, P. R. China Full list of author information is available at the end of the article
}

at $25 \%-55 \%$ around the world (Fleischmann et al. 2016; Degoricija et al. 2006). The lung is extremely vulnerable to damage in various pathologies, including ischemiareperfusion injury, post-injury multiple organ failure, influenza virus infections and sepsis, which lead to acute lung injury (ALI) (Ciesla et al. 2005; Hengst et al. 2010; Jochems et al. 2018).

Among numerous causes of ALI, overwhelming inflammation, overproduction of reactive oxygen species (ROS), endotoxin release into the circulation and capillary leakage are the main contributors (Chen et al. 2014; Wheeler and Bernard 2007). It is known that the barrier function of the pulmonary capillary endothelial is almost uniformly disrupted in septic ALI, which contributes to 
adverse outcomes (Birukov et al. 2013). And it is likely that this endothelium disfunction also results in a systemic cytokine storm, which causes inflammatory cell infiltration and further promotes inflammation response (Bhattacharya and Matthay 2013). The pathological process of ALI incorporates the alveolar-capillary membrane and the adhesion, activation of inflammatory cells, which deteriorate the damage to organisms (Wang et al. 2002; Aggarwal et al. 2014). Base on this, treating sepsis by alleviating pulmonary dysfunction is one of the potential therapeutic methods. Unfortunately, various mechanical ventilation and drug therapies have failed to distinctly improve sepsis survival until now (Matthay et al. 2019). Therefore, therapeutic opinions that can effectively remedy and decrease the mortality of sepsis must be urgently established.

Fibroblast growth factor-2 (FGF2), also known as basic fibroblast growth factor, is the first discovered prototypical members of the FGF family, which plays pleiotropic roles in cellular and metabolic homeostasis (Li 2019). A study shown that FGF2 stimulated migration and proliferation of endothelial cells in vivo and inhibit inflammation (Zbinden et al. 2018; Decker et al. 2016). Another reported that FGF2 cooperating with IL-17 promoted the pathogenesis of autoimmune arthritis, other reported FGF2 suppressed the neuroinflammation through the FGF2-ERK1/2 signaling, demonstrating that FGF2 inactivated ERK1/2 in the hippocampus and the microglial marked by Iba1 in CA1, CA2, CA3 and DG (Shao et al. 2017; Tang et al. 2017). To ascertain whether the FGF2 positively or negatively affected the inflammation in ALI, we examined its role in vivo and vitro.

\section{Materials and methods \\ Reagents and antibodies}

LPS (Escherichia coli O111:B4) and peroxidase from horseradish (HRP, P8375) were purchased from Sigma Aldrich Company. Human recombinant FGF2 (100-18B) was acquired from PeproTech. Evans Blue (0109A14) was bought from Leagene, China. Wright-Giemsa (G1020), $4 \%$ paraformaldehyde (P1110), 5\% BSA (SW3015) and Triton X-100 (T8200) were procured from Solarbio Life Sciences (Beijing, China). Anti-GAPDH (SC-47724), anti- $\alpha$-E-catenin (SC-9988), anti-IL-6 (SC-57315), antiROBO4 (SC-166872) and anti-F4/80 (SC-377009) were bought from Santa Cruz Biotechnology Inc., (Santa Cruz, CA). Anti-AKT (4691), anti-p-AKT (4060), anti- $\beta$-actin (4970), anti-P65 (9936), anti-p-P65 (9936), anti-P38 (8690), anti-p-P38 (9216), anti-IL-1 $\beta$ (12242), anti-TNF- $\alpha$ (3707) and DAPI (4083) were acquired from Cell Signaling Technology, USA. Anti-VE-cadherin (ab33168), anti-rabbit IgG H\&L (FITC, ab6717), anti-Mouse IgG $\mathrm{H} \& \mathrm{~L}(\mathrm{Cy} 3, \mathrm{ab} 97035)$ and anti-mouse IgG H\&L (FITC, ab6785) were obtained from Abcam (Cambridge, MA). Anti-cyclooxygenase 2 (COX2, bs-0732R) was acquired from Bioss Inc. (Beijing, China). Anti-mouse HRP-conjugated polyclonal antibody (170-6516) and anti-rabbit HRP-conjugated polyclonal antibody (170-6515) were garnered from Bio-Rad, USA. Phenylmethanesulfonyl fluoride (PMSF) were acquired from Beyotime, China. BCA kit and Radio-Immunoprecipitation Assay (RIPA) were received from Thermo Scientific, USA. Protein phosphatase inhibitor mixture (P1260) was gained from Applygen (Beijing, China).

\section{Animals}

Male C57BL/6 mice (8-10 weeks old, $18-25$ g/body) were purchased from Shanghai SLAC Laboratory, Animal Limited Liability Company (Shanghai, China). The animals were fed in accordance with the local animal welfare policy with an ambient temperature of $23 \pm 3{ }^{\circ} \mathrm{C}$, a relative humidity of $55 \% \pm 10 \%$, and a 12 light/dark cycle according to the Institutional Animal Care and Use Committee's guidelines.

\section{CLP and animal tests}

The mice were anaesthetized and prepared for the CLP model as previously described (Giano et al. 2014). The mice were randomly divided into three groups: sham, CLP and CLP with FGF2. Simply, mice were operated with an abdominal incision, the cecum was ligated and punctured twice with a 21-gauge needle (Kindly, Shanghai, China) to gently extrude some feces. Then the cecum was put back to the abdominal cavity and the abdomen was sutured carefully. The sham group was operated in the skin and abdominal muscle rather than subjected to CLP, and the CLP with FGF2 was peritoneally injected with $0.1 \mathrm{mg} / \mathrm{kg}$ of FGF2 protein $6 \mathrm{~h}$ after surgery. The untreated group was given equal amounts of phosphate buffered saline (PBS). All the mice were immediately injected with $1 \mathrm{ml}$ of pre-warmed saline post-operation immediately. All mice were assessed every $12 \mathrm{~h}$ for the following 4 days and euthanized at the moribund stage. The experimental samples were collected $24 \mathrm{~h}$ after CLP.

\section{ELISA test}

The plasma was measured using the ELISA Kit of Tumor Necrosis Factor- $\alpha$ (TNF- $\alpha$ ) and interleukin-6 (IL-6) (R\&D Systems, Inc., USA). The laboratory procedure was manipulated according to manufacturer's instructions. Simply put, every reagent was placed in pore plate for a period of time and cleaned many times. When the color developed, the reaction liquid didn't be poured out but added the stop solution. The result was tested by a microplate reader (Molecular Devices, Hercules, CA, USA). 


\section{Proteome Profiler Array analyses}

One mouse was selected from each group by detecting the content of various indexes in the Mouse Angiogenesis Antibody Proteome Profiler Array (R\&D Systems, Inc., USA). All array data were processed in accordance with the manufacturer's instructions. The result was examined by VilBer LouRMAT (Bio-Rad, Universal Hood II, USA).

\section{Histology}

The three groups of mice were sacrificed, and the right lung was harvested as previously described ( $\mathrm{Xu}$ et al. 2018). Formalin-fixed tissues were processed for $4 \mathrm{~h}$, embedded in paraffin and cut into $3 \mathrm{~mm}$ sections. Then, the sections were stained with hematoxylin and eosin (H\&E). All sections were examined and graded based on an arbitrary four-grade scale (Zhou et al. 2007). The result was assessed in terms of airway epithelial necrosis, intra-alveolar edema, hyaline membranes, hemorrhage, and the recruitment of inflammatory cells into the air space.

\section{Wet/dry weight ratio}

The left lung was blot up of the blood on the surface of the tissue for weighing and recording. Afterward, lung was placed in a dryer at $60{ }^{\circ} \mathrm{C}$ for $72 \mathrm{~h}$ and then reweighed to calculate the wet/dry (W/D) weight ratio.

\section{Pulmonary permeability}

Pulmonary permeability was assessed as previously described (Yang et al. 2017). All mice were administered with $200 \mu \mathrm{l}$ of $5 \%$ Evans Blue through a tail vein injection at $1 \mathrm{~h}$ prior to execution. The mice were narcotized and immobilized on a frame to perform transcardial perfusion with normal saline until the lung paled. Then the lung was harvested, washed, weighed and immerged in $1 \mathrm{ml} / 100 \mathrm{mg}$ of formamide. After incubation at $60{ }^{\circ} \mathrm{C}$ for $24 \mathrm{~h}$, the optical density (OD) value of the supernatant was detected by microplate reader (Molecular Devices, Hercules, CA, USA).

\section{Collection of broncho-alveolar lavage fluid (BALF)}

The mice were anesthetized and fixed to collect the BALF as previously described (Yang et al. 2015). The lung tissues were lavaged thrice with $1 \mathrm{ml}$ of PBS and filtrated with a metal net. The total cell number and the different cell types were determined using cytological smears, and the protein level was evaluated by the BCA kit (Thermo Scientific, USA).

\section{Cell culture and experiments}

Human pulmonary microvascular endothelial cells (HPMECs, 3000, ScienCell, USA) were cultured in endothelial cell medium (ECM, 1001, ScienCell, USA), matched with $5 \%$ fetal bovine serum (FBS) and $1 \%$ penicillin/streptomycin in a humidified incubator under $5 \% \mathrm{CO}_{2}$ at $37{ }^{\circ} \mathrm{C}$. The HPMECs were seeded into the culture dish for one night. The medium was replaced with fetal bovine serum (FBS) medium for $6-8 \mathrm{~h}$. The HPMECs were cultured with $1 \mu \mathrm{g} / \mathrm{ml}$ LPS with or without $50 \mathrm{ng} / \mathrm{ml}$ of FGF2 for $0.5 \mathrm{~h}$ or $6 \mathrm{~h}$.

Peritoneal macrophages (PMs) were isolated from 6-8 weeks old male C57BL/6 mice. Briefly, mice were intraperitoneal injected with $2 \mathrm{ml}$ Starch broth (Sigma, USA), and then cold RPMI 1640 medium was used to wash the peritoneal cavity several times to isolate peritoneal exudate cells. The cells were cultured in a humidified incubator for $2 \mathrm{~h}$ and the adhered cells were collected as macrophages for further experiments. PMs were cultured with $1 \mu \mathrm{g} / \mathrm{ml}$ LPS with or without $50 \mathrm{ng} / \mathrm{ml}$ of FGF2 for $0.5 \mathrm{~h}$ or $6 \mathrm{~h}$.

\section{Endothelial tube formation assay}

Briefly, the HPMECs $(10 \times 104$ cells/well $)$ were seeded into 24-well plates, which were covered with $120 \mu \mathrm{l}$ of polymerized matrigel (Corning, 354234). Then the HPMECs were treated with $1 \mu \mathrm{g} / \mathrm{ml} \mathrm{LPS}$ with or without $50 \mathrm{ng} / \mathrm{ml}$ of FGF2. After incubation for $3.5 \mathrm{~h}$ at $37{ }^{\circ} \mathrm{C}$ under $5 \% \mathrm{CO} 2$, images were captured with an Olympus CKX41 light microscope. Each experiment was performed at least three times.

\section{HPMECs permeability assay}

The HPMECs $\left(5 \times 10^{4} /\right.$ well $)$ were seeded in the upper chamber of 24 -well Transwell plate $(0.4 \mu \mathrm{m}$ pore size; Corning Incorporated, NY) cultured at $37{ }^{\circ} \mathrm{C}$ under $5 \%$ $\mathrm{CO}_{2}$ until a monolayer was formed. After LPS stimulation, the HRP determined the permeability of the HPMECs permeability by measuring the concentration of the HRP in the lower chamber. The HRP was diluted with the cell culture medium, and $200 \mu \mathrm{l}$ of HRP solution was added to the apical compartment at a concentration of $50 \mathrm{ng} / \mathrm{ml}$. After the addition of HRP for $15 \mathrm{~min}, 10 \mu \mathrm{l}$ of fluid was collected from the basolateral compartment of each filter. This fluid was added to 96-well plates together with $150 \mu \mathrm{l}$ substrate and incubated at $37^{\circ} \mathrm{C}$ for $10 \mathrm{~min}$. Then, sulfuric acid was added to terminate the reaction. The OD value was measured with a microplate reader.

\section{Immunofluorescence}

The $4 \mu \mathrm{m}$ thickness lung sections were dewaxed, rehydrated, and antigens retrieved by sodium citrate buffer (0.01 M, pH 6.0) for $10 \mathrm{~min}$. The pre-treated lung sections were blocked with $5 \%$ BSA for $30 \mathrm{~min}$ and incubated with the primary antibodies overnight at $4{ }^{\circ} \mathrm{C}$. The sections were then incubated with Alexa Fluor labeled 
secondary antibody for $1 \mathrm{~h}$ at room temperature and nuclei were stained with DAPI for $5 \mathrm{~min}$.

HPMECs were fixed, permeabilized, blocked, and incubated with primary antibodies overnight at $4{ }^{\circ} \mathrm{C}$. The slides were then incubated with Alexa Fluor labeled secondary antibody for $1 \mathrm{~h}$ at room temperature and DAPI staining for $5 \mathrm{~min}$. Images were obtained with a laser confocal microscope (Leica, Germany).

\section{Western blotting}

The samples were dissociated by RIPA with $1 \%$ PMSF and $1 \%$ protein phosphatase inhibitor mixture, and the protein concentrations were detected using a BCA kit. The equivalent protein was separated by electrophoresis, transferred, blocked and incubated with the first antibodies overnight at $4{ }^{\circ} \mathrm{C}$. The polyvinylidene difluoride (PVDF) membranes (EDM Millipore, Billerica, MA) were incubated with homologous species secondary antibody. After incubation, the membranes were detected by using ECL Chemiluminescent Reagent (Advansta, USA).

\section{Quantitative real-time RT-PCR}

Trizol reagent (Invitrogen, CA) was added to every sample and the RNA was extracted using the Trizol reagent (Invitrogen, CA). The cDNA synthesis was performed using the GoScript Reverse Transcription System kit (Promega, USA) according to the manufacturer's protocols. Quantitative real-time polymerase chain reaction (qRT-PCR) was performed with LightCycler (Roche Diagnostics, Mannheim, Germany) and SYBR Green (Roche Diagnostics, Mannheim, Germany). The primer sequences are listed in Tables 1 and 2.

\section{Statistical analyses}

Statistical analyses were conducted using SPSS software version 20.0 (SPSS Inc., IL, USA). The categorized

Table 1 Mouse primer sequences for the real-time PCR

\begin{tabular}{lll}
\hline Gene & Forward primer & Reverse primer \\
\hline GAPDH & GCACAGTCAAGGCCGAGAAT & GCCTTCTCCATGGTGGTGAA \\
IL-1 $\beta$ & TGCCACCTTTTGACAGTGATG & TTCTTGTGACCCTGAGCGAC \\
IL-6 & GCCTTCTTGGGACTGATGCT & TGTGACTCCAGCTTATCTCTTGG \\
IL-10 & TAAGGCTGGCCACACTTGAG & GTTTTCAGGGATGAAGCGGC \\
TNF-a & ACCCTCACACTCACAAACCA & ACCCTGAGCCATAATCCCCT \\
CXCL1 1 & GGATGCCACAGGATTCCATA & GTGCCATCAGAGCAGTCTGT \\
CXCL10 & CCAAGTGCTGCCGCTCAT & TCCCTATGGCCCTCATTCTCA \\
MCP-1 & TTTC & \\
& CAAAACCAAA & \\
TLR4 & TGCAAGGAGGTTCAGTGCTC & AGTGAATGAGCCCCAGCAAA \\
ICAM1 & TTCTCATGCCGCACAGAACT & TCCTGGCCTCGGAGACATTA \\
\hline
\end{tabular}

Table 2 Human primer sequences for the real-time PCR

\begin{tabular}{lll}
\hline Gene & Forward primer & Reverse primer \\
\hline GAPDH & GGAGTCCACTGGCGTCTTC & GGTTCACACCCATGACGAAC \\
IL-1 $\beta$ & ATGATGGCTTATTACAGTGGCAA & GTCGGAGATTCGTAGCTGGA \\
IL-6 & ACCCCCAATAAATATAGGACT & AGAAGGCAACTGGACCGAAG \\
& GGA & \\
IL-10 & TACGGCGCTGTCATCGATTT & TAGAGTCGCCACCCTGATGT \\
TNF-a & TGGGATCATTGCCCTGTGAG & GGTGTCTGAAGGAGGGGGTA \\
CXCL1 & GCAGGGATTCACCCCAAGA & GGTAGCCCTTGTTTCCCCC \\
CXCL10 & AGCAGAGGAACCTCCAGTCT & ATGCAGGTACAGCGTACAGT \\
MCP-1 & TTCCCCTAGCTTTCCCCAGA & TCCCAGGGGTAGAACTGTGG \\
\hline
\end{tabular}

variables between groups were examined using one-way ANOVA or Student's t test. All data are presented as means $\pm \mathrm{SD}$ (standard deviation). $\mathrm{P}<0.05$ was considered statistically significant.

\section{Results \\ FGF2 reduces the inflammatory response and improves the survival in septic mice}

To verify whether FGF2 exerted a protective effect against sepsis, the mice were intraperitoneally injected with FGF2 at $6 \mathrm{~h}$ post-operation. Our results showed that FGF2 administration reduced the mortality in septic mice (Fig. 1a), which followed by a down-regulation of plasma inflammatory factors (TNF- $\alpha$ and IL-6) expression (Fig. 1b). In addition, the proteome profiler array was conducted to verify that the other elevated cytokines, such as CXCL1, CXCL10, CXCL16, MCP1, MMP8, and IL-10 in the CLP group were decreased by FGF2 treatment (Fig. 1c).

\section{FGF2 protects the pulmonary function and mitigates the injury in septic ALI}

The lung is extremely impaired by acute injury, and ALI is one of the complications of severe sepsis. To investigate whether FGF2 reduced the pulmonary injury caused by CLP, the lung sections were subjected to H\&E staining for histological examination. Briefly, the pulmonary alveoli were not of uniform size and the alveolar septum was thicker in the CLP group than in the sham group. In comparison, the FGF2-treated group was improved (Fig. 2a). The mean lung injury score in the CLP group was $13 \pm 1.79$, which was much higher than that $(4.17 \pm 1.17)$ of the sham group and that $(9.17 \pm 1.72)$ of the FGF2 group (Fig. 2a). Likewise, the lung wet/dry ratio was reduced in FGF2 group compared with CLP group (Fig. 2b). To measure the capillary function, we observed its permeability using Evans Blue dye assay and found that the hyper-permeability in the CLP group was reversed by FGF2. (Fig. 2c). Afterwards, we measured the 


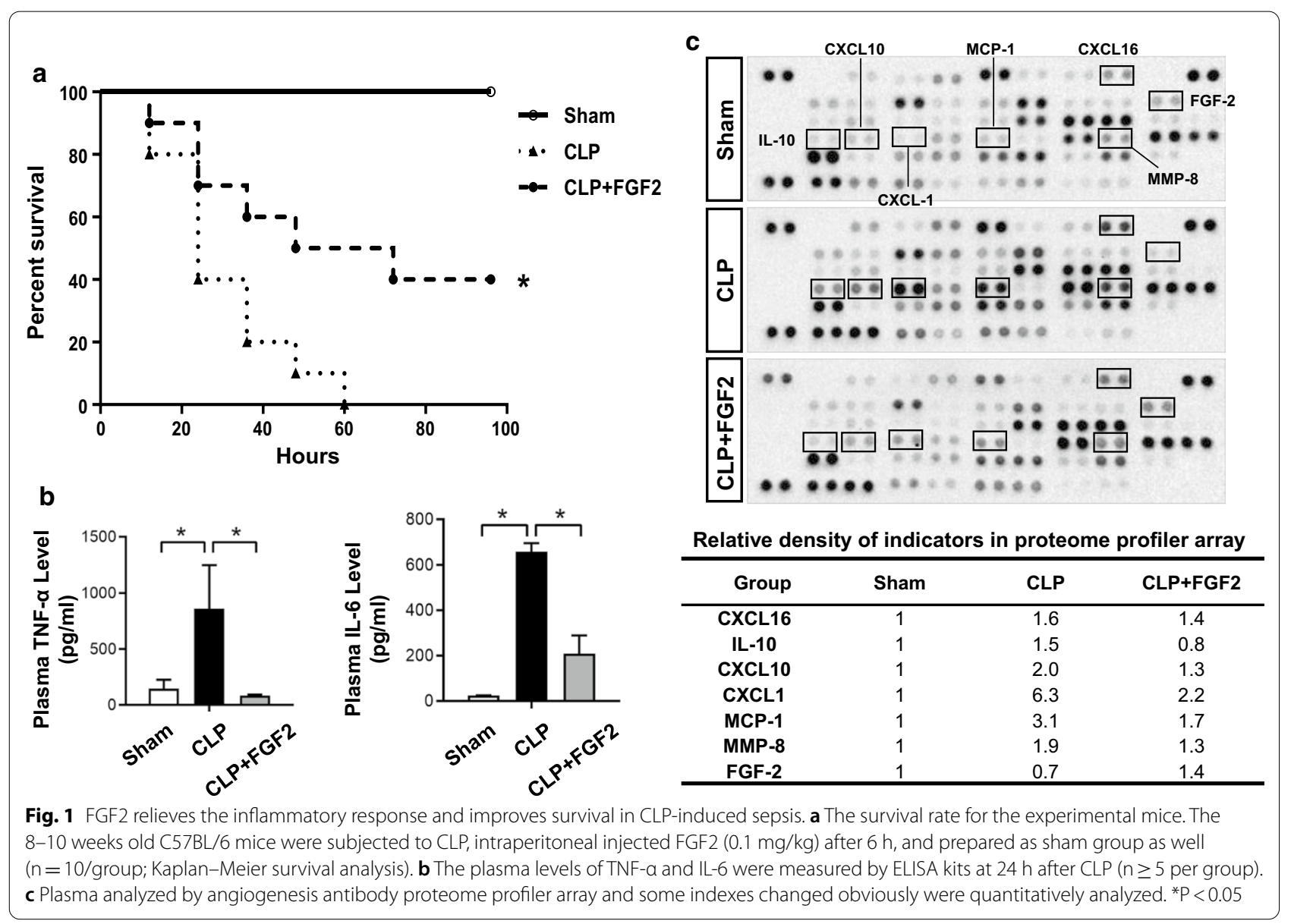

cells and concentration of protein in the BALF. We found that the count of total cells and protein in the BALF were increased in CLP group, while decreased by FGF2 administration (Fig. 2c, d).

\section{FGF2 attenuates the pulmonary inflammation in sepsis}

Moreover, the qRT-PCR analyses for lung tissues indicated that the mRNA expressions of TLR4, IL-6, IL-10, CXCL1, CXCL10, MCP-1 and intercellular cell adhesion molecule-1 (ICAM-1) in CLP group were higher than that in sham and FGF2-treated group (Fig. 3a). Besides, IL- 6 and other inflammatory mediators, which included the TNF- $\alpha$, IL- $1 \beta$ and COX 2 protein expression, were elevated in CLP mice, while declined under FGF2 treatment (Fig. 3b). ROBO4, which is related to endothelial permeability, is one of the most important functional proteins of vessel (London et al. 2010). Our findings revealed that the FGF2 effectively improved the ROBO4 expression which was decreased in CLP lungs (Fig. 3b). As the adhesion of macrophages was related to the chemokines, such that macrophages sticking occurred in the injured lungs. We labeled F4/80 in lung tissues and found that the CLP group had more macrophages than the control group and FGF2 group (Fig. 3c).

\section{FGF2 alleviates the inflammation caused by LPS in HPMECs via $\mathrm{P} 38 / \mathrm{AKT} / \mathrm{NF}-\mathrm{KB}$ signaling}

Basing on the different mensuration time points and concentration, we chose the most suitable condition as follows: $50 \mathrm{ng} / \mathrm{ml}$ of FGF2 concentration for $6 \mathrm{~h}$ but $30 \mathrm{~min}$ to phosphorylate protein. To protect against exogenous damage, angiopoiesis would occur in the phase of new tissue formation. The tube formation assay revealed that the HPMECs stimulated by LPS had a higher tube formation capacity than that of the PBS and FGF2 managed groups (Fig. 4a). According to the data in vivo, the proteins of IL-1 $\beta$ and IL- 6 were tested by Western blot analysis, which showed that both indexes of the LPS group were more expressed than the control group, while decreased under FGF2 treatment (Fig. 4b). The 
a
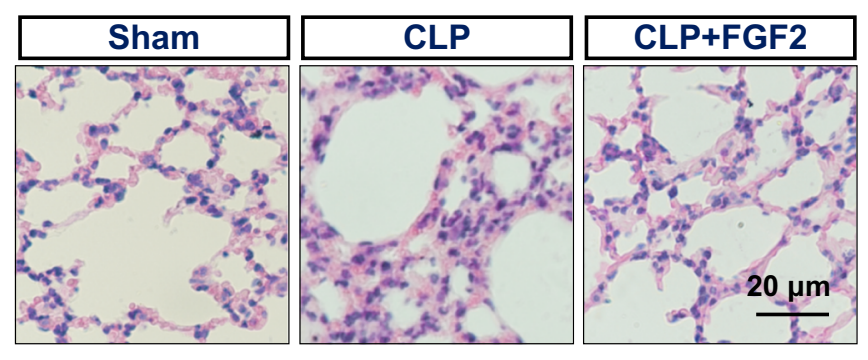
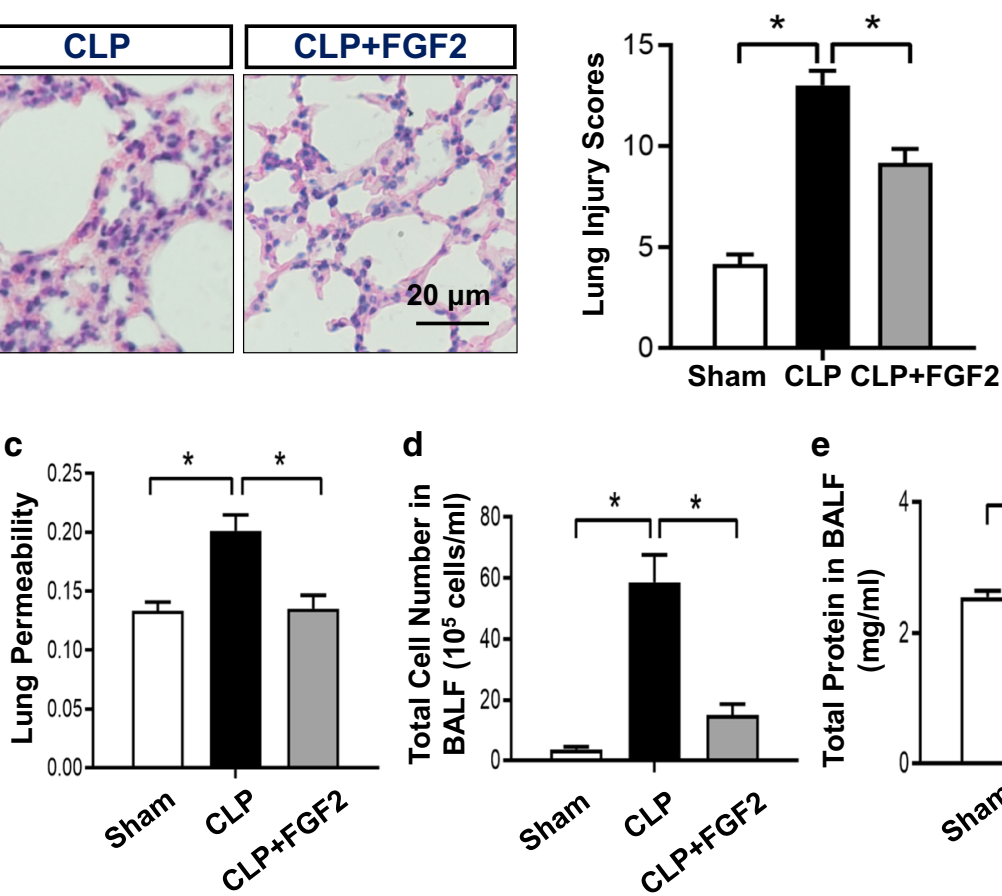

d

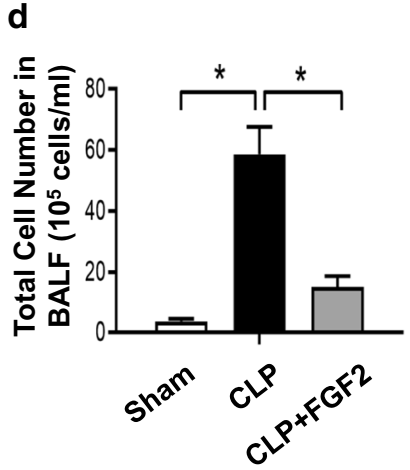

Fig. 2 FGF2 controls the pathology and hyperosmotic state in septic lungs. a The different groups of lung tissue sections were stained by hematoxylin-eosin (H\&E) and analyzed by the lung injury scores. b The lung levels of wet/dry weight ratio. The formula: ratio= (wet-dry)/wet ( $n \geq 5$ per group). $\mathbf{c}$ The measurement of Evans Blue permeated into mesenchyme of lung reflecting the permeability of vessel was detected by microplate reader ( $n \geq 5$ per group). $\mathbf{d}$ Total cell numbers in BALF were calculated with hemacytometer ( $n \geq 5$ per group). e The protein level of BALF was evaluated by the BCA kit ( $n \geq 5$ per group). Data are represented as mean $\pm S E M$. *P $<0.05$

inflammatory mediators mRNA levels of IL-1 $\beta$, IL-6, IL-10, TNF- $\alpha$, CXCL1, CXCL10 and MCP-1 in LPS group were elevated compared to those of the PBS control group, while reduced in FGF2 group except for TNF- $\alpha$ and CXCL1 levels (Fig. 4c). In addition, we checked the relative pathways in HPMECs and found that P38 activation by phosphorylated P38 (p-P38), AKT activation by phosphorylated AKT (p-AKT) and NF- $\mathrm{KB}$ activation by phosphorylated P65 (p-P65) under LPS challenge were inhibited by FGF2 administration (Fig. 4d). Therefore, these results demonstrated that FGF2 controlled the inflammatory mediators through $\mathrm{P} 38 / \mathrm{AKT} / \mathrm{NF}-\mathrm{kB}$ signaling pathways in HPMECs.

\section{FGF2 protects HPMECs from the LPS-induced injury.}

To verify the contribution of FGF2 in improving the capillary leakage, the expression of VE-cadherin and $\alpha$-E-catenin proteins, as representatives of the interlinkage in endothelial cells, were subjected to double-color immunofluorescence when the cells formed a monolayer. In the diagram, the HPMECs junction indicated by VEcadherin and $\alpha$-E-catenin immunofluorescence staining suffered from a disruption caused by LPS, although the FGF2 group was not as persecuted as the LPS group (Fig. 5a). However, the immunoblotting results showed that neither LPS nor FGF2 had impacts on VE-cadherin and $\alpha$-E-catenin protein level in cell lysate (Fig. 5b). The concentration of HRP passed into the lower chamber reflected the integrity of the HPMECs. We found that the worsen HRP leakage induced by LPS stimulation was partly recovered with FGF2 administration (Fig. 5c).

\section{FGF2 reduced the LPS-stimulated inflammatory factors production through $\mathrm{P} 38 / \mathrm{AKT} / \mathrm{NF}-\mathrm{KB}$ signaling}

As FGF2 can effectively inhibit the pulmonary infiltration of macrophages in septic mice (Fig. 3c), we extracted peritoneal macrophages to check whether the proinflammatory condition in macrophages induced by LPS was controlled by FGF2 administration. Our results showed that the increasing mRNA levels of IL-1 $\beta$, IL- 6 and TNF- $\alpha$ caused by LPS stimulation were down-regulated by FGF2 administration (Fig. 6a). Unsurprisingly, the activation of P38/AKT/NF- $\mathrm{kB}$ pathways in macrophages by LPS challenge were restrained by FGF2 treatment 


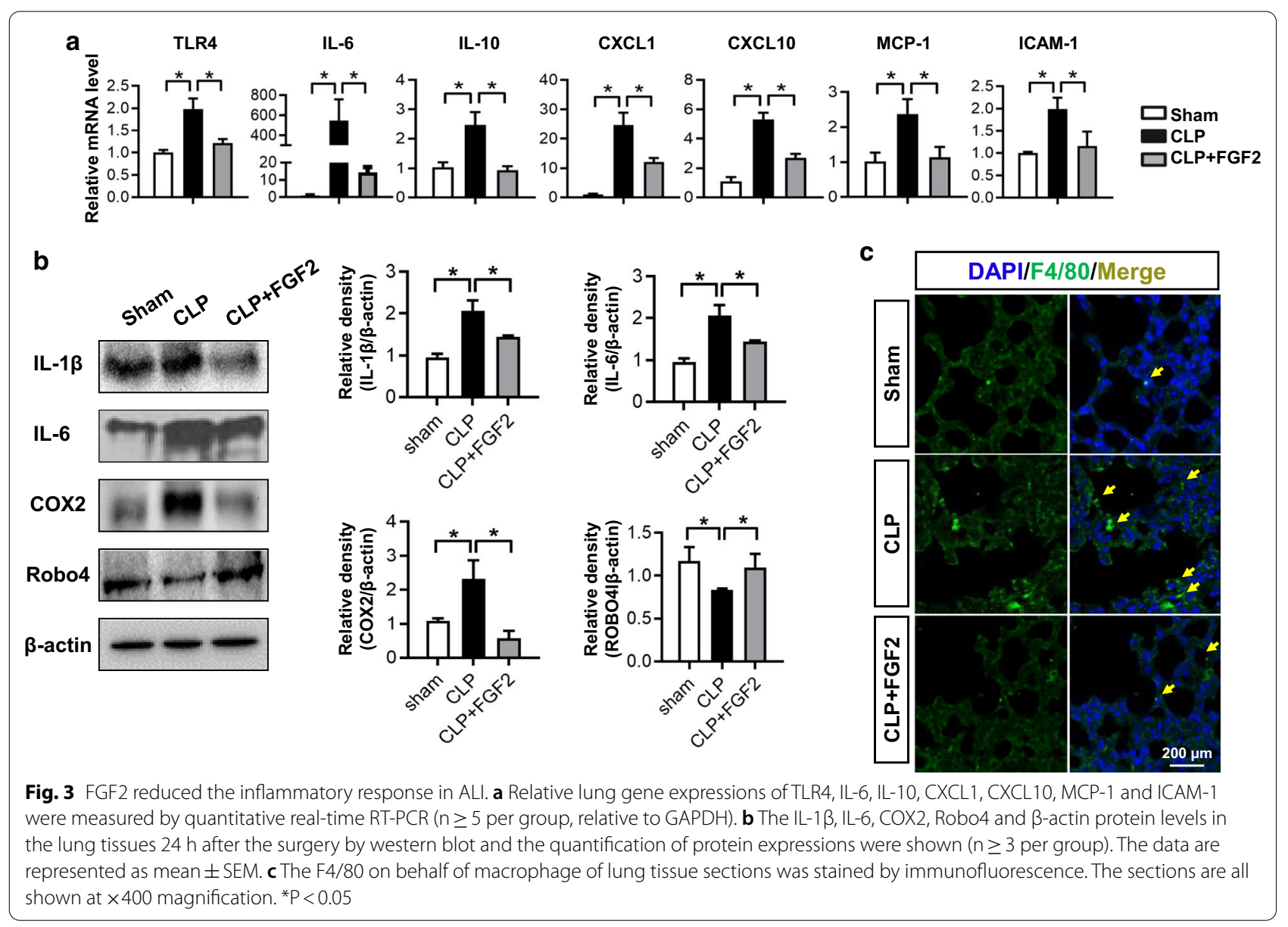

(Fig. 6b). These findings revealed that FGF2 reduced the proinflammatory factors in macrophages via P38/AKT/ NF- $\mathrm{B}$ pathways.

\section{Discussion}

Sepsis is considered as a systemic inflammatory response to infection, When pathogen-associated molecular patterns (PAMPs) on the surface of pathogens are recognized by related receptors on the body's immune system cells, the immune activation pathway of infection was stimulated (Boyd et al. 2014), for example by activating NF- $\mathrm{kB}$ signaling pathways and neutrophils cells releasing proinflammatory and anti-inflammatory mediators (Hotchkiss and Karl 2003), cytokines and complement activation (Cecconi et al. 2018). The body has an inflammatory hyperreaction to infection, and organ dysfunction caused by uncontrolled inflammation leads to death. Our research confirmed that intraperitoneal injection of FGF2 reduced the level of serum inflammatory factors, including CXCL1, CXCL10, CXCL16, MCP1, MMP8, and IL-10, which may be the possible reason for the decreased mortality of mice in the CLP.

The lung is considered to be the primary target organ damaged by sepsis, leading to ALI, and or even developing acute respiratory distress syndrome (ARDS), which is the main cause of sepsis death (Bao et al. 2010; Phua et al. 2009). The pathogenesis of ALI is a series of inflammatory mediators released by neutrophils, macrophages, endothelial cells and other cells. Inflammatory cells and mediators infiltrate into the lung, causing increased pulmonary microvascular permeability, pulmonary interstitial, alveolar edema and alveolar destruction, resulting in acute hypoxic respiratory insufficiency or respiratory failure (Herold et al. 2013). The results from both laboratory and pathological experiments in our study confirmed that after FGF2 treatment the infiltration of inflammatory factors in the lungs of CLP mice were reduced thereby reducing lung damage in mice.

As a member of the FGF family, the role of FGF2 in organ development, tissue repair, regeneration, and 

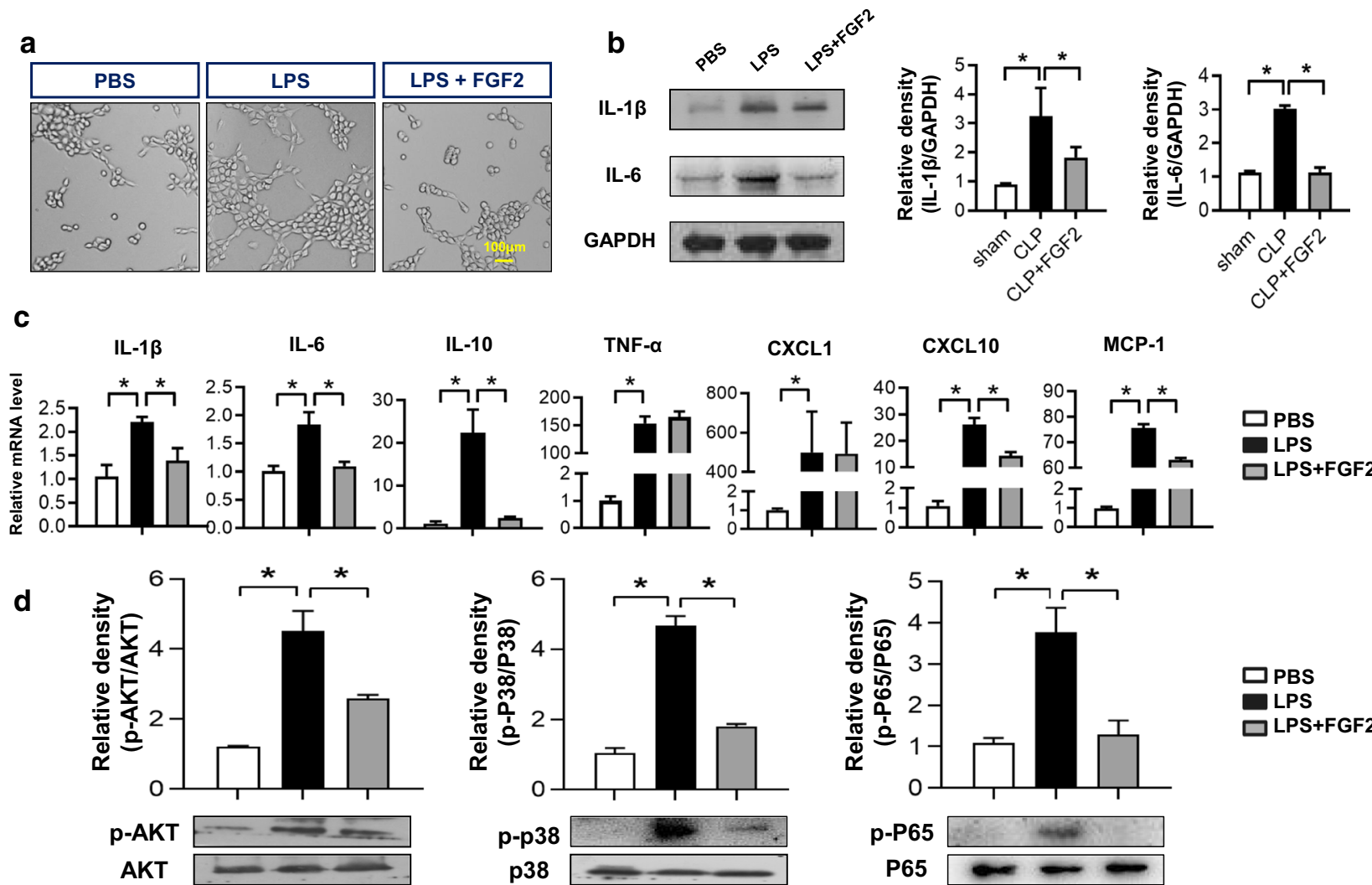

IL-10

TNF- $\alpha$

CXCL1

CXCL10

MCP-1
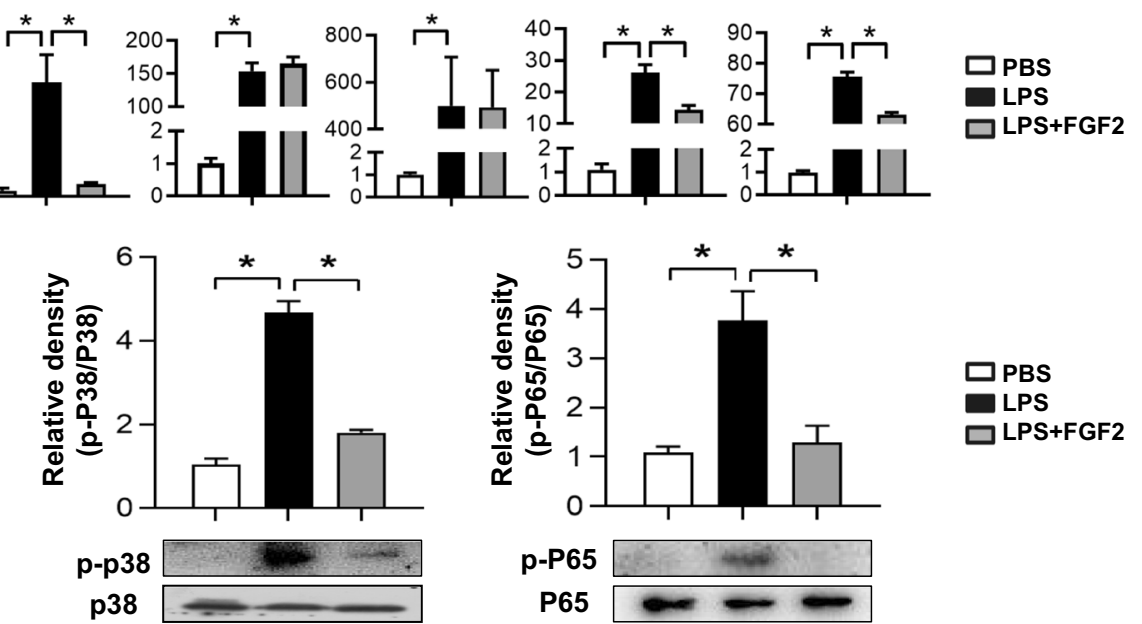

Fig. 4 FGF2 relieves lung endothelial cells inflammation induced by LPS. a Tube formation assay. HPMECs were seeded into 24-well plates covered with Matrigel antecedently in different medium and observed $3.5 \mathrm{~h}$ after LPS (1 $\mathrm{mg} / \mathrm{ml})$ with/without FGF2 (50 $\mathrm{ng} / \mathrm{ml})$ stimulation. b The inflammatory cytokine IL-1 $\beta$ and IL-6 protein levels of HPMECs $6 \mathrm{~h}$ after LPS were assessed by western blot and relative densities were analyzed ( $n \geq 3$ per group, GAPDH as a internal control)., while the protein levels of $p-p 38, p 38, p-A K T$, AKT, p-ERK and ERK was affected 0.5 h. c Relative gene expressions of inflammatory factors IL-1 $\beta, I L-6, I L-10$, TNF- $a, C X C L 1, C X C L 10$ and MCP-1 was measured by quantitative real-time RT-PCR ( $n \geq 4$ per group). Data are represented as mean \pm SEM. $\mathbf{d}$ The protein expressions of p-P38, P38, p-AKT, AKT, p-P65 and P65 in HPMECs which were stimulated by LPS for $0.5 \mathrm{~h}$ were measured by western blot analysis and relative densities were quantified respectively ( $n \geq 3$ per group). ${ }^{*} P<0.05$

diseases has been widely investigated (Beenken and Mohammadi 2009). FGF2 promoted cell proliferation, activated migration and induced changes in cell shapes in many organs to leading diseases, such as breast cancer, corneal endothelial cells, cartilage regeneration and so on (Ricard et al. 2014; Song et al. 2015; Lee et al. 2018). However, whether the FGF2 has a therapeutic effect in sepsis and ALI has never been reported.

Inflammation is the main cause of endothelial barrier hyperosmolarity, which is associated with ALI and acute respiratory distress syndrome (ARDS) (Matthay et al. 2019; Barabutis et al. 2018). Inflammatory factors adhere activated immune cells to the blood vessel wall through ICAM1, synthesize chemokines to attract immune cells, endothelial cell dysfunction and necrosis that lead to increased vascular permeability (Chousterman et al. 2017), our study found that after FGF-2 treatment in mice, ICAM-1 expression decreased in lung tissue, which may reduce pulmonary capillary leakage and reduce the wet-to-dry weight ratio of mouse lungs. Even more, the proinflammatory cytokines storm breaks the barrier function of endothelial cells, endothelial injury will promote inflammation (Zbinden et al. 2018; Flemming et al. 2015), therefore, FGF2 promotes the repair of lung endothelial cells and reduces lung inflammation. ROBO4 is related to endothelial permeability, is one of the most important functional proteins of vessel, inflammatory stimulus damaged the barrier function of vessel through $\mathrm{ROBO} 4$-slit signaling pathway (London et al. 2010). Our data suggested that the administration 
a

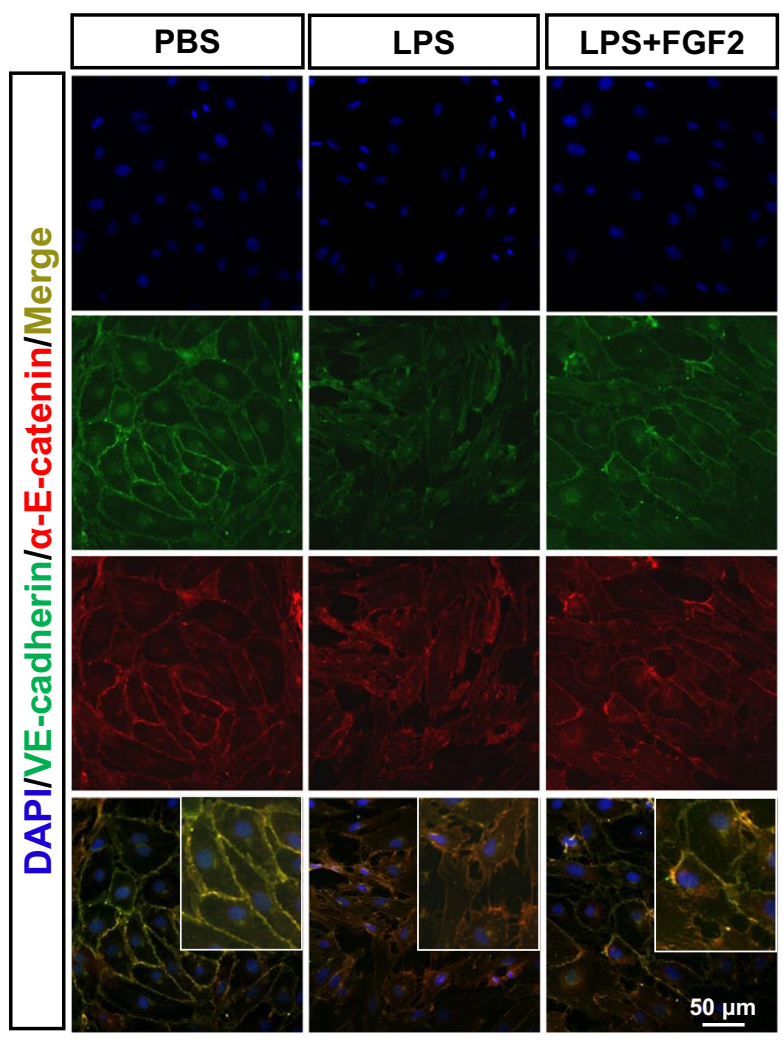

b
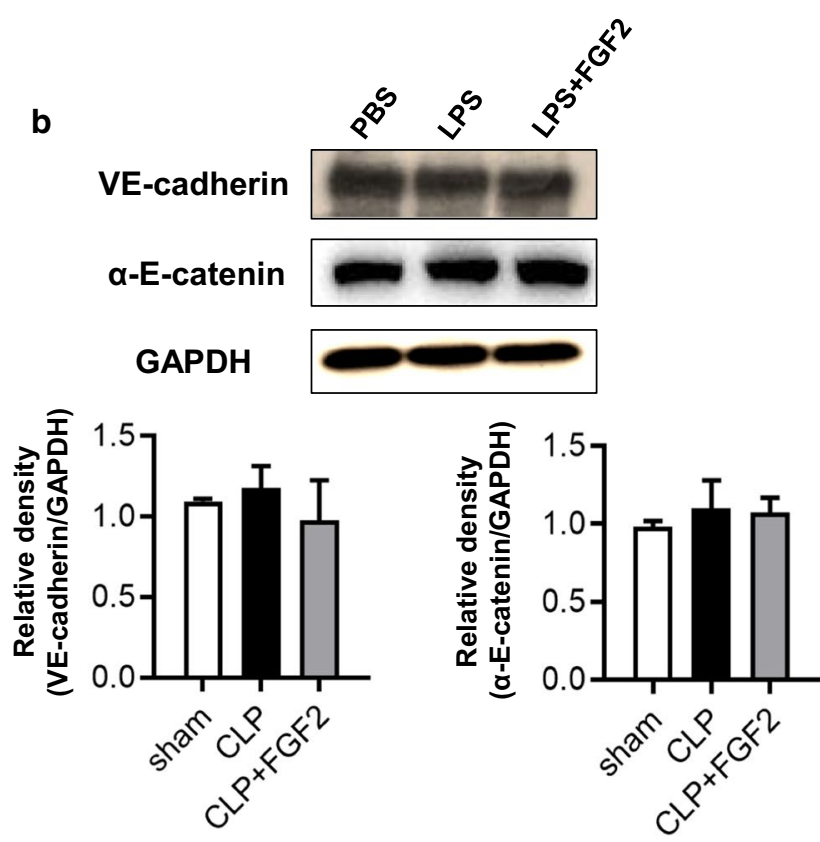

C

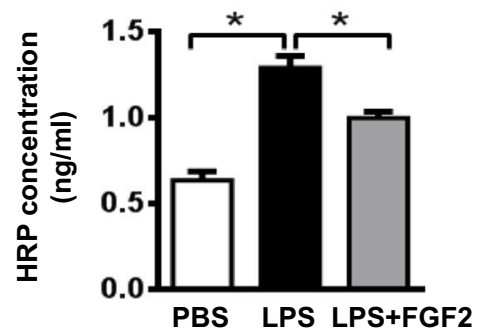

Fig. 5 FGF2 protects the HPMECs permeability from LPS by stabilizing VE-cadherin and a-E-catenin. a The VE-cadherin and a-E-catenin was stained by cytofluorometry. The pictures are all shown at $\times 400$ magnification. $\mathbf{b}$ The protein levels of intercellular connectivity VE-cadherin and a-E-catenin in HPMECs $6 \mathrm{~h}$ after LPS were evaluated by western blot and the relative densities were analyzed ( $\mathrm{n} \geq 3$ per group, GAPDH was used as internal control). c HPMECs were seeded into the upper chamber of Transwell $(0.4 \mu \mathrm{m})$ with different treatments for measuring the HRP condition ( $\mathrm{n} \geq 3$ per group). Data are represented as mean \pm SEM. * $P<0.05$

of FGF2 can effectively modulate the CLP-induced ALI and also our finding also revealed that the CLP-induced decline of ROBO4 protein expression may rescued by FGF2 followed with alleviated inflammation cells infiltration in lungs.

Previous studies revealed that it is effective to inhibit Influenza H1N1 Virus Infection through regulating the expression of FGF2 by miR-194 (Wang et al. 2017). In this report, we demonstrated that FGF2 alleviated pulmonary inflammation and improved the survival in CLP mice. Moreover, we showed that FGF2 inhibited pulmonary injury and improved capillary permeability through regulating inflammatory mediators.
The endothelium is a part of the vascular system that regulates the exchange of molecules and fluids between blood circulation and body tissue compartments (Wettschureck et al. 2019). Various cytokines and chemokines contribute to endothelial cell damage and/or transient compromise of the endothelial barrier function (Harrison 2010; Teijaro et al. 2011). The proinflammatory cytokines storm breaks the barrier function of endothelial cells and the junction between VE-cadherin and $\alpha$-E-catenin through ROBO4-slit signal (London et al. 2010; Yu et al. 2014; Rocheteau et al. 2015). Meanwhile, the inflammatory mediators regulatory mechanisms were highly related to mitogenactivated protein kinase (MAPK) and NF- $\mathrm{kB}$ signaling 


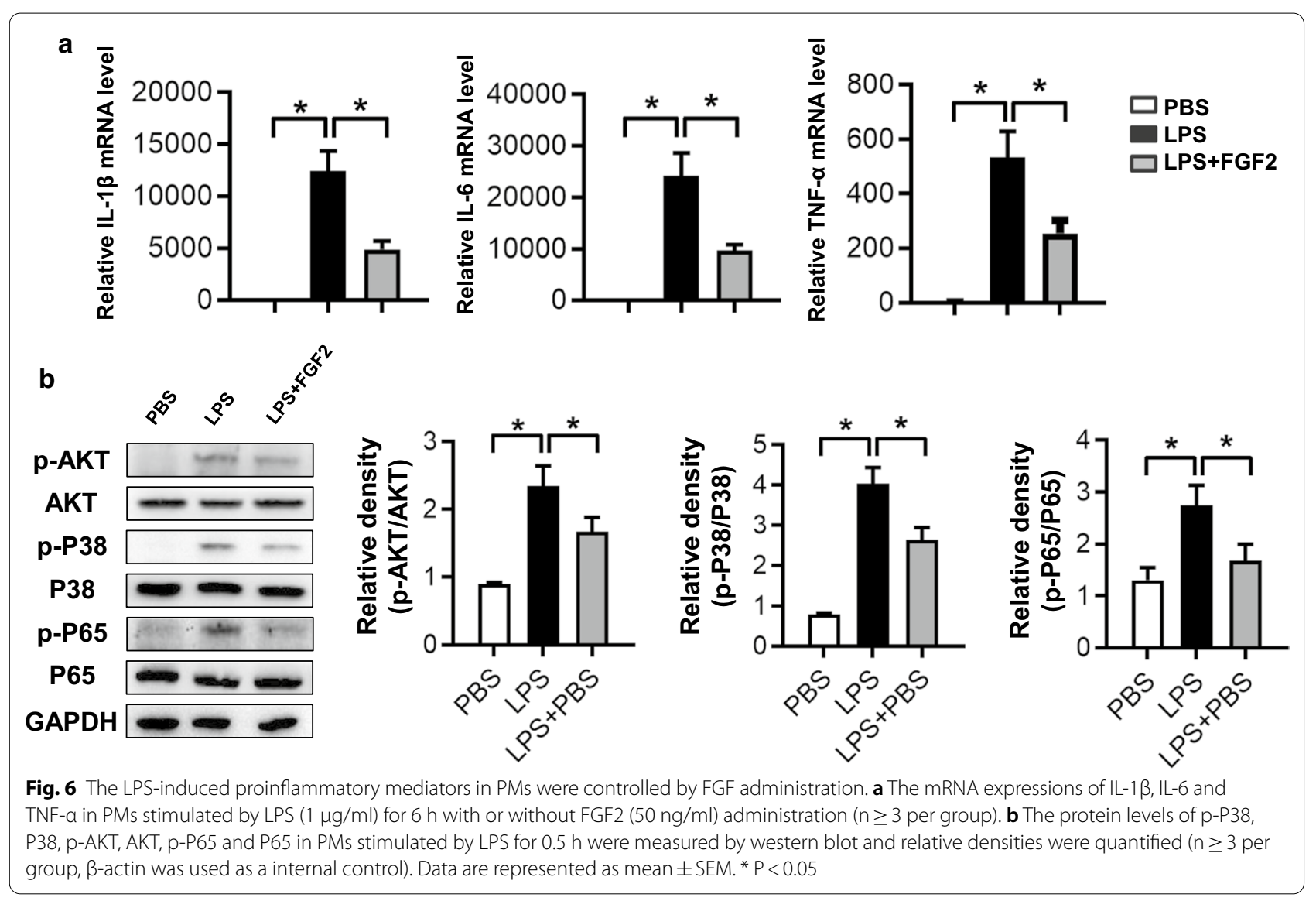

pathways during pathological process of sepsis. Herein, we reported that FGF2 not only markedly controlled inflammation by regulating inflammatory factors, chemotactic factors via P38/AKT/NF- $\kappa B$ pathways, but also protected the link of VE-cadherin and $\alpha$-E-catenin proteins on the cell membrane to hold the linkage in
LPS-challenged HPMECs (Fig. 7). In addition, our results also revealed that the increasing proinflammatory mediator productions induced by LPS in peritoneal macrophages were reduced by FGF2. 


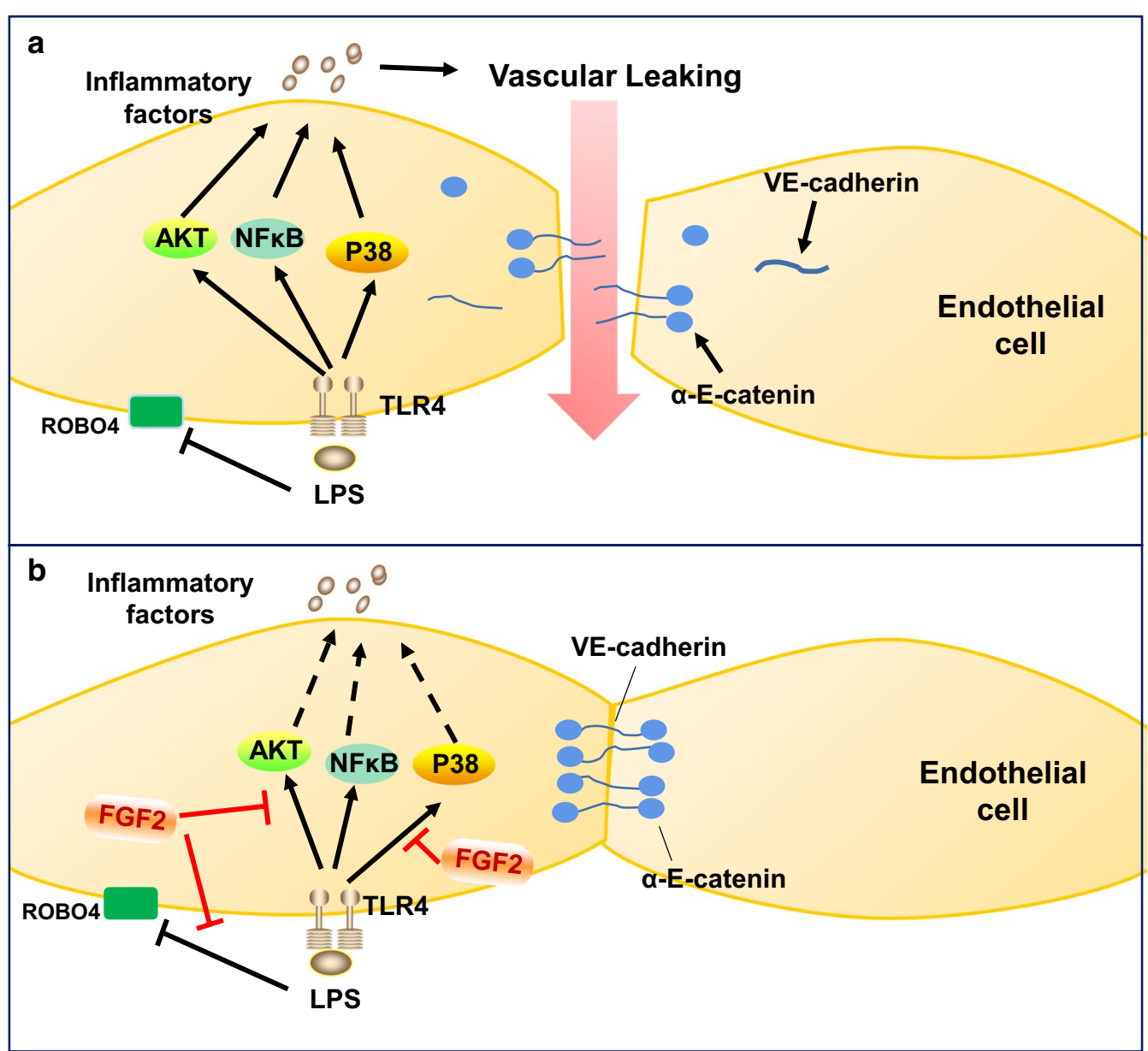

Fig. 7 FGF2 alleviates the inflammation and vascular leakage in sepsis. FGF2 reduces vascular leakage caused by relieving inflammation through AKT/P38/NF-KB pathways. a LPS combined with TLR4 activates AKT/P38/NF-KB pathways to release amount of inflammatory factors leading to VE-cadherin/a-E-catenin disruption and endothelial cell barrier malfunction. b FGF2 enhances vascular barrier function against inflammatory factors production by inactivating AKT/P38/NF-KB pathways and stabilizing VE-cadherin/a-E-catenin at the cell surface

\section{Conclusion}

FGF2 was beneficial in sepsis-induced ALI by alleviating inflammation and attenuating endothelial permeability via P38/AKT/NF-kB pathways, which indicated that FGF2 is a new promising treatment for sepsis.

\section{Abbreviations}

ERK: Extracellular regulated protein kinases; BSA: Bovine serum Albumin; GAPDH: Glyceraldehyde-phosphate dehydrogenase; IL: Interleukin; DAPI: 4',6-Diamidino-2-phenylindole; ELISA: Enzyme-linked Immunosorbent Assay; RPMI: 1640 Rswell park memorial institute; HRP: Peroxidase from horseradish; PMs: Peritoneal macrophages; HPMEC: Human pulmonary microvascular endothelial cells.

\section{Acknowledgements}

Not applicable.

\section{Authors' contributions}

XP was responsible for experimental design, acquisition of data, interpretation of data and drafting the manuscript. SX was responsible for formal analysis, interpretation of data, Statistical analysis. ZZ was responsible for conception and design and formal analysis, supervision. FW and LM were responsible for conception and design, data curation, supervision, review and editing. CW and JW were responsible for acquisition formal analysis, and interpretation of data. YH was responsible for review and editing. JP, DL and CW were responsible for project administration, Critical revision of the manuscript for important intellectual content and review and editing. All authors read and approved the final manuscript.

\section{Funding}

This work was supported by the National Natural Science Foundation of China (81873949, 81671968 and 8197894), the Natural Science Foundation of Zhejiang Province of China (LY17H150003) and the Medical Innovation Discipline of Zhejiang Province (Critical Care Medicine, Y2015), the project of Wenzhou Municipal Science and Technology Bureau (2018ZY002), the medical and health research project of Zhejiang Province of China (WKJ-ZJ-1909).

Availability of data and materials Not applicable. 


\section{Ethics approval and consent to participate}

The study was approved by the Professional Ethics Committee of Clinical Research, (The First Affiliated Hospital of Wenzhou Medical University).

\section{Consent for publication}

Not applicable.

\section{Competing interests}

The authors declare no competing financial interests.

\section{Author details}

1 Department of Intensive Care Unit, The First Affiliated Hospital of Wenzhou Medical University, Wenzhou 325000, Zhejiang, P. R. China. ${ }^{2}$ Department of Intensive Care Unit, Hangzhou Third Hospital, Hangzhou 310000, Zhejiang, P. R. China. ${ }^{3}$ Wenzhou Medical University, Wenzhou 325000, Zhejiang, P. R. China. ${ }^{4}$ The Yiwu Affiliated Hospital of Wenzhou Medical University, Jinhua 322000, Zhejiang, P. R. China. ${ }^{5}$ Department of Traumatology Medicine, The First Affiliated Hospital of Wenzhou Medical University, Wenzhou 325000, Zhejiang, P. R. China.

Received: 2 March 2020 Accepted: 29 September 2020

Published online: 13 November 2020

\section{References}

Aggarwal S, Gross CM, Kumar S, Dimitropoulou C, Sharma S, Gorshkov BA, Sridhar S, Lu Q, Bogatcheva NV, Jezierska-Drutel AJ, Lucas R, Verin AD, Catravas JD, Black SM. Dimethylarginine dimethylaminohydrolase II overexpression attenuates LPS-mediated lung leak in acute lung injury. Am J Respir Cell Mol Biol. 2014;50(3):614-25. https://doi.org/10.1165/ rcmb.2013-01930C.

Bao S, Liu MJ, Lee B, Besecker B, Lai JP, Guttridge DC, Knoell DL. Zinc modulates the innate immune response in vivo to polymicrobial sepsis through regulation of NF-kappaB. Am J Physiol Lung Cell Mol Physiol. 2010;298(6):L744-754. https://doi.org/10.1152/ajplung.00368.2009.

Barabutis N, Dimitropoulou C, Gregory B, Catravas JD. Wild-type p53 enhances endothelial barrier function by mediating RAC1 signalling and RhoA inhibition. J Cell Mol Med. 2018;22(3):1792-804. https://doi.org/10.1111/ jcmm.13460.

Beenken A, Mohammadi M. The FGF family: biology, pathophysiology and therapy. Nat Rev Drug Discovery. 2009;8(3):235-53. https://doi. org/10.1038/nrd2792.

Bhattacharya J, Matthay MA. Regulation and repair of the alveolar-capillary barrier in acute lung injury. Annu Rev Physiol. 2013;75:593-615. https:// doi.org/10.1146/annurev-physiol-030212-183756

Birukov KG, Zebda N, Birukova AA. Barrier enhancing signals in pulmonary edema. Compre Physiol. 2013;3(1):429-84. https://doi.org/10.1002/ cphy.c100066.

Boyd JH, Russell JA, Fjell CD. The meta-genome of sepsis: host genetics, pathogens and the acute immune response. J Innate Immunity. 2014;6(3):272-83. https://doi.org/10.1159/000358835.

Cecconi M, Evans L, Levy M, Rhodes A. Sepsis and septic shock. Lancet (London, England). 2018;392(10141):75-87. https://doi.org/10.1016/ s0140-6736(18)30696-2.

Chen HH, Chang CL, Lin KC, Sung PH, Chai HT, Zhen YY, Chen YC, Wu YC, Leu $\mathrm{S}$, Tsai TH, Chen $\mathrm{CH}$, Chang HW, Yip HK. Melatonin augments apoptotic adipose-derived mesenchymal stem cell treatment against sepsisinduced acute lung injury. Am J Transl Res. 2014;6(5):439-58.

Chousterman BG, Swirski FK, Weber GF. Cytokine storm and sepsis disease pathogenesis. Semin Immunopathol. 2017;39(5):517-28. https://doi. org/10.1007/s00281-017-0639-8.

Ciesla DJ, Moore EE, Johnson JL, Burch JM, Cothren CC, Sauaia A. The role of the lung in postinjury multiple organ failure. Surgery. 2005;138(4):749-57. https://doi.org/10.1016/j.surg.2005.07.020.

Decker CG, Wang Y, Paluck SJ, Shen L, Loo JA, Levine AJ, Miller LS, Maynard HD. Fibroblast growth factor 2 dimer with superagonist in vitro activity improves granulation tissue formation during wound healing. Biomaterials. 2016;81:157-68. https://doi.org/10.1016/j.biomaterials.2015.12.003.
Degoricija V, Sharma M, Legac A, Gradiser M, Sefer S, Vucicevic Z. Survival analysis of 314 episodes of sepsis in medical intensive care unit in university hospital: impact of intensive care unit performance and antimicrobial therapy. Croatian Med J. 2006;47(3):385-97.

den Hengst WA, Gielis JF, Lin JY, Van Schil PE, De Windt LJ, Moens AL. Lung ischemia-reperfusion injury: a molecular and clinical view on a complex pathophysiological process. Am J Physiol Heart Circ Physiol. 2010;299(5):H1283-1299. https://doi.org/10.1152/ajpheart.00251.2010.

Fleischmann C, Scherag A, Adhikari NK, Hartog CS, Tsaganos T, Schlattmann P, Angus DC, Reinhart K. Assessment of global incidence and mortality of hospital-treated sepsis. Current estimates and limitations. Am J Res Crit Care Med. 2016;193(3):259-72. https://doi.org/10.1164/rccm.20150 4-07810C.

Flemming S, Burkard N, Renschler M, Vielmuth F, Meir M, Schick MA, Wunder C, Germer CT, Spindler V, Waschke J, Schlegel N. Soluble VE-cadherin is involved in endothelial barrier breakdown in systemic inflammation and sepsis. Cardiovasc Res. 2015;107(1):32-44. https://doi.org/10.1093/cvr/ cVv144.

Giano MC, Ibrahim Z, Medina SH, Sarhane KA, Christensen JM, Yamada Y, Brandacher G, Schneider JP. Injectable bioadhesive hydrogels with innate antibacterial properties. Nat Commun. 2014;5:4095. https://doi. org/10.1038/ncomms5095.

Harrison C. Sepsis: calming the cytokine storm. Nat Rev Drug Discovery. 2010;9(5):360-1. https://doi.org/10.1038/nrd3162.

Herold S, Gabrielli NM, Vadász I. Novel concepts of acute lung injury and alveolar-capillary barrier dysfunction. Am J Physiol Lung Cell Mol Physiol. 2013;305(10):L665-681. https://doi.org/10.1152/ajplung.00232.2013.

Hotchkiss RS, Karl IE. The pathophysiology and treatment of sepsis. N Engl J Med. 2003;348(2):138-50. https://doi.org/10.1056/NEJMra021333.

Jochems SP, Marcon F, Carniel BF, Holloway M, Mitsi E, Smith E, Gritzfeld JF, Solorzano C, Reine J, Pojar S, Nikolaou E, German EL, Hyder-Wright A, Hill H, Hales C, de Steenhuijsen Piters WAA, Bogaert D, Adler H, Zaidi S, Connor V, Gordon SB, Rylance J, Nakaya HI, Ferreira DM. Inflammation induced by influenza virus impairs human innate immune control of pneumococcus. Nat Immunol. 2018;19(12):1299-308. https://doi. org/10.1038/s41590-018-0231-y.

le Wang F, Patel M, Razavi HM, Weicker S, Joseph MG, McCormack DG, Mehta S. Role of inducible nitric oxide synthase in pulmonary microvascular protein leak in murine sepsis. Am J Respir Crit Care Med. 2002;165(12):16349. https://doi.org/10.1164/rccm.2110017.

Lee JG, Jung E, Heur M. Fibroblast growth factor 2 induces proliferation and fibrosis via SNAI1-mediated activation of CDK2 and ZEB1 in corneal endothelium. J Biol Chem. 2018;293(10):3758-69. https://doi. org/10.1074/jbc.RA117.000295.

Li X. The FGF metabolic axis. Front Med. 2019;13(5):511-30. https://doi. org/10.1007/s11684-019-0711-y.

London NR, Zhu W, Bozza FA, Smith MC, Greif DM, Sorensen LK, Chen L, Kaminoh Y, Chan AC, Passi SF, Day CW, Barnard DL, Zimmerman GA, Krasnow MA, Li DY. Targeting Robo4-dependent Slit signaling to survive the cytokine storm in sepsis and influenza. Sci Transl Med. 2010;2(23):2319. https://doi.org/10.1126/scitranslmed.3000678.

Matthay MA, Zemans RL, Zimmerman GA, Arabi YM, Beitler JR, Mercat A, Herridge M, Randolph AG, Calfee CS. Acute respiratory distress syndrome. Nat Rev Dis Primers. 2019;5(1):18. https://doi.org/10.1038/s4157 2-019-0069-0.

Phua J, Badia JR, Adhikari NK, Friedrich JO, Fowler RA, Singh JM, Scales DC, Stather DR, Li A, Jones A, Gattas DJ, Hallett D, Tomlinson G, Stewart TE, Ferguson ND. Has mortality from acute respiratory distress syndrome decreased over time?: A systematic review. Am J Respir Crit Care Med. 2009;179(3):220-7. https://doi.org/10.1164/rccm.200805-7220C.

Rhodes A, Evans LE, Alhazzani W, Levy MM, Antonelli M, Ferrer R, Kumar A, Sevransky JE, Sprung CL, Nunnally ME, Rochwerg B, Rubenfeld GD, Angus DC, Annane D, Beale RJ, Bellinghan GJ, Bernard GR, Chiche JD, Coopersmith C, De Backer DP, French CJ, Fujishima S, Gerlach H, Hidalgo JL, Hollenberg SM, Jones AE, Karnad DR, Kleinpell RM, Koh Y, Lisboa TC, Machado FR, Marini JJ, Marshall JC, Mazuski JE, McIntyre LA, McLean AS, Mehta S, Moreno RP, Myburgh J, Navalesi P, Nishida O, Osborn TM, Perner A, Plunkett CM, Ranieri M, Schorr CA, Seckel MA, Seymour CW, Shieh L, Shukri KA, Simpson SQ, Singer M, Thompson BT, Townsend SR, Van der Poll T, Vincent JL, Wiersinga WJ, Zimmerman JL, Dellinger RP. Surviving 
Sepsis Campaign: International Guidelines for Management of Sepsis and Septic Shock: 2016. Intensive Care Med. 2017;43(3):304-77. https://doi. org/10.1007/s00134-017-4683-6.

Ricard N, Tu L, Le Hiress M, Huertas A, Phan C, Thuillet R, Sattler C, Fadel E, Seferian A, Montani D, Dorfmuller P, Humbert M, Guignabert C. Increased pericyte coverage mediated by endothelial-derived fibroblast growth factor-2 and interleukin- 6 is a source of smooth muscle-like cells in pulmonary hypertension. Circulation. 2014;129(15):1586-97. https://doi. org/10.1161/circulationaha.113.007469.

Rocheteau P, Chatre L, Briand D, Mebarki M, Jouvion G, Bardon J, Crochemore C, Serrani P, Lecci PP, Latil M, Matot B, Carlier PG, Latronico N, Huchet C, Lafoux A, Sharshar T, Ricchetti M, Chretien F. Sepsis induces long-term metabolic and mitochondrial muscle stem cell dysfunction amenable by mesenchymal stem cell therapy. Nat Commun. 2015;6:10145. https://doi. org/10.1038/ncomms10145.

Shao X, Chen S, Yang D, Cao M, Yao Y, Wu Z, Li N, Shen N, Li X, Song X, Qian Y. FGF2 cooperates with IL-17 to promote autoimmune inflammation. Scientific Rep. 2017;7(1):7024. https://doi.org/10.1038/s41598-017-07597-8.

Song X, Dai D, He X, Zhu S, Yao Y, Gao H, Wang J, Qu F, Qiu J, Wang H, Li X, Shen N, Qian Y. Growth factor FGF2 cooperates with interleukin-17 to repair intestinal epithelial damage. Immunity. 2015;43(3):488-501. https://doi. org/10.1016/j.immuni.2015.06.024

Tang MM, Lin WJ, Zhang JT, Zhao YW, Li YC. Exogenous FGF2 reverses depressive-like behaviors and restores the suppressed FGF2-ERK1/2 signaling and the impaired hippocampal neurogenesis induced by neuroinflammation. Brain Behav Immun. 2017;66:322-31. https://doi.org/10.1016/j. bbi.2017.05.013.

Teijaro JR, Walsh KB, Cahalan S, Fremgen DM, Roberts E, Scott F, Martinborough E, Peach R, Oldstone MB, Rosen H. Endothelial cells are central orchestrators of cytokine amplification during influenza virus infection. Cell. 2011;146(6):980-91. https://doi.org/10.1016/j.cell.2011.08.015.

Wang K, Lai C, Gu H, Zhao L, Xia M, Yang P, Wang X. miR-194 inhibits innate antiviral immunity by targeting FGF2 in influenza H1N1 virus infection. Front Microbiol. 2017;8:2187. https://doi.org/10.3389/fmicb.2017.02187.
Wettschureck N, Strilic B, Offermanns S. Passing the vascular barrier: endothelial signaling processes controlling extravasation. Physiol Rev. 2019;99(3):1467-525. https://doi.org/10.1152/physrev.00037.2018.

Wheeler AP, Bernard GR. Acute lung injury and the acute respiratory distress syndrome: a clinical review. Lancet (London, England). 2007;369(9572):1553-64. https://doi.org/10.1016/s0140-6736(07)60604-7.

Xu S, Zhou Z, Li H, Liu Z, Pan X, Wang F, Huang Y, Li X, Xiao Y, Pan J, Wang C, Li D. BMSCs ameliorate septic coagulopathy by suppressing inflammation in cecal ligation and puncture-induced sepsis. J Cell Sci. 2018. https://doi. org/10.1242/jcs.211151.

Yang SH, Kao TI, Chiang BL, Chen HY, Chen KH, Chen JL. Immune-modulatory effects of bu-zhong-yi-qi-tang in ovalbumin-induced murine model of allergic asthma. PLoS ONE. 2015;10(6):e0127636. https://doi.org/10.1371/ journal.pone.0127636.

Yang WW, Yang LQ, Zhao F, Chen CW, Xu LH, Fu J, Li SL, Ge XY. Epiregulin promotes lung metastasis of salivary adenoid cystic carcinoma. Theranostics. 2017;7(15):3700-14. https://doi.org/10.7150/thno.19712.

Yu J, Zhang X, Kuzontkoski PM, Jiang S, Zhu W, Li DY, Groopman JE. Slit2N and Robo4 regulate lymphangiogenesis through the VEGF-C/ VEGFR-3 pathway. Cell Commun Signal. 2014;12:25. https://doi. org/10.1186/1478-811x-12-25

Zbinden A, Browne S, Altiok El, Svedlund FL, Jackson WM, Healy KE. Multivalent conjugates of basic fibroblast growth factor enhance in vitro proliferation and migration of endothelial cells. Biomater Sci. 2018;6(5):1076-83. https ://doi.org/10.1039/c7bm01052d.

Zhou GJ, Zhang H, Zhi SD, Jiang GP, Wang J, Zhang M, Gan JX, Xu SW, Jiang GY. Protective effect of raloxifene on lipopolysaccharide and acid-induced acute lung injury in rats. Acta Pharmacol Sin. 2007;28(10):1585-90. https ://doi.org/10.1111/j.1745-7254.2007.00637.x.

\section{Publisher's Note}

Springer Nature remains neutral with regard to jurisdictional claims in published maps and institutional affiliations. 